\title{
UPAYA MENINGKATKAN HASIL BELAJAR PPKN SISWA DENGAN MENERAPKAN MODEL PEMBELAJARAN KOOPERATIF TIPE MAKE A MATCH DI KELAS VIII UPTD SMP NEGERI 3 KEC. AKABILURU TAHUN PELAJARAN 2020/2021
}

\author{
Raiman Faizal \\ UPTD SMP Negeri 3 Kecamatan Akabiluru, \\ Kabupaten Lima Puluh Kota \\ email: faizalkoto@gmail.com
}

\begin{abstract}
This study is aimed to see the improvement of student learning outcomes in Civics subjects through the application of the Make A Match cooperative learning model in class VIII UPTD SMP Negeri 3 Kec. Akabiluru Academic Year 2020/2021. The type of the research conducted is classroom action research $(C A R)$. This research was conducted in two cycles, where each cycle consisted of activities that included planning, action, observation, and reflection. This research was conducted in UPTD SMP Negeri 3 Kec.Akabiluru. The research subjects were students of class VIII at UPTD SMP Negeri 3 Kec. Akabiluru which amounted to 26 students. The object of this research is the improvement of student learning outcomes in class VIII on Civics subjects. The results show that the value of student learning outcomes in Pre-Cycle activities are: The highest score is 70, the lowest value is 25 and the average value is 56.73. Meanwhile, the value of student learning outcomes in cycle 1, the highest value is 100, the lowest value is 25, while the average value is 61.34. In the second cycle, the highest value is 100, the lowest value is 60 while the average value is 81.88. Thus, it can be concluded that the average value of student learning outcomes has increased, where in the first cycle is 61.34 to an increase in the average learning outcomes in the second cycle to 81.88. The average score of students in the first cycle with the second cycle is 71.61 with an increase in value of 20.54. Based on the description above, it can be concluded that the use of the Make A Match cooperative learning model can improve student Civic learning outcomes in class VIII UPTD SMP Negeri 3 Kec. Akabiluru Academic Year 2020/2021.

: Civics learning outcomes, Cooperative Learning, Make a match

Keywords
\end{abstract}

\begin{abstract}
Abstrak
Penelitian ini bertujuan untuk melihat peningkatan hasil belajar siswa pada mata pelajaran PPKn melalui penerapan model pembelajaraan kooperatif tipe make A Match di kelas VIII UPTD SMP Negeri $3 \mathrm{Kec}$. Akabiluru Tahun Pelajaran 2020/2021. Jenis penelitian yang dilakukan yaitu Penelitian Tindakan Kelas (PTK). Penelitian ini dilakukan melalui dua siklus, dimana setiap siklus terdiri atas kegiatan yang meliputi perencanaan, tindakan, obsevasi dan refleksi. Penelitian ini dilaksanakan di UPTD SMP Negeri $3 \mathrm{Kec}$. Akabiluru. Subyek penelitian ini adalah siswa kelas VIII di UPTD SMP Negeri 3 Kec. Akabiluru yang berjumlah 26 orang. Objek dalam penelitian ini yaitu peningkatan hasil belajar siswa di kelas VIII pada mata pelajaran PPKn. Hasil penelitian menunjukkan bahwa nilai hasil belajar siswa pada kegiatan Pra-Siklus adalah : Nilai tertinggi 70 , nilai terendahnya adalah 25 dan nilai-rata-ratanya adalah
\end{abstract}


56,73. Sementara itu nilai hasil hasil belajar siswa pada siklus 1 nilai tertingginya adalah 100, nilai terendahnya adalah 25 sedangkan rata-rata nilainya adalah 61,34 . Pada siklus ke 2, nilai tertingginya adalah 100, nilai terendahnya adalah 60 sedangkan nilairata-ratanya adalah 81,88. Dengan demikian dapat disimpulkan bahwa nilai rata-rata hasil belajar siswa terdapat peningkatan, dimana pada siklus 1 adalah 61,34 menjadi naik rata-rata hasil belajarnya pada siklus ke 2 menjadi 81,88. Rata-rata hasil nilai siswa pada siklus I dengan siklus ke II adalah 71,61 dengan peningkatan nilainya sebesar 20,54. Berdasarkan uraian di atas, dapat ditarik kesimpulan bahwa penerapan model pembelajaran kooperatif tipe Make A Match dapat meningkatkan hasil belajar PPKn siswa di kelas VIII UPTD SMP Negeri 3 Kec. Akabiluru Tahun Pelajaran 2020/2021.

Kata Kunci: Hasil belajar PPKn, Pembelajaran Kooperatif, Make a match

\section{PENDAHULUAN}

Proses pemberlangsungan pendidikan dapat dilakukan melalui tiga cara, yaitu melalui pendidikan formal, pendidikan in-formal dan pendidikan non formal. Pendidikan formal adalah proses pendidikan yang dilaksanakan diberbagai sekolah secara teratur, sistematis, bertingkat atau berjenjang dengan mengikuti syarat-syarat yang jelas di lembaga pendidikan tersebut. Pendidikan in-formal adalah proses pelaksanaan pendidikan yang dilaksanakan dilingkungan keluarga atau rumah tangga yang berbentuk kegiatan belajar secara mandiri. Sedangkan pendidikan non-formal adalah proses pelaksanaan pendidikan yang dilaksanakan atau diperoleh diluar lembaga pendidikan formal yang dapat dilaksanakan secara terstruktur dan berjenjang. Ketiga macam pendidikan ini harus saling bersinergi dalam upaya mewujudkan keberhasilan pendidikan seperti pendidikan yang dialami oleh seorang siswa yang dilakukan di lembaga pendidikan formal mulai dari jenjang terendah sampai ke jenjang pendidikan tertinggi sekalipun, tidak terlepas dari pendidikan yang diperolehnya dari lingkungan in-formal maupun lingkungan non-formal sebelumnya saat ia masih kecil, sebelum memasuki bangku pendidikan formal. Hal ini disebabkan bahwa keberhasilan seseorang dalam pendidikannya dilingkungan pendidikan formal sangat bergantung dari pendidikan in-formal dan non-formal yang diperoleh sebelumnya, terutama pendidikan in-formal keluarga, karena pendidikan keluarga dari kedua orang tuanya adalah pendidikan pertama dan utama yang amat menentukan keberhasilan dimasa depannya. Berbicara tentang lingkungan pendidikan formal, seiring dengan perkembangan dan kemajuan zaman saat ini, maka sudah selayaknya perlu diadakan inovasi dan kreasi dalam dunia pendidikan ini, yaitu dengan cara melakukan penemuan, penciptaan dan pelaksanaan dalam praktekpraktek pembelajaran terhadap siswa di sekolah.

Salah satu inovasi dan kreasi yang dimaksudkan tersebut di atas adalah dengan menciptakan dan melaksanakan berbagai model-model pembelajaran yang kreatif dan inovatif dalam pembelajaran oleh seorang guru terhadap siswanya di sekolah. Hal ini bertujuan agar proses pembelajaran yang berlangsung disekolah dapat lebih enerjik, hangat, penuh gairah dan bersemangat sehingga hasil akhir dari proses pembelajaran yang ingin dicapai oleh kedua pihak yaitu siswa maupun guru bisa lebih baik, menggembirakan serta membanggakan kepada kwalitas mutu dan produk lulusan serta sekolah itu sendiri sebagai almamater pendidikan. Perlu disadari dan dipahami oleh guru sebagai mediator berbagai ilmu pengetahuan dan keterampilan kepada para siswa, bahwa seorang guru mempunyai tanggung jawab 
moril supaya bagaimana proses kegiatan pembelajaran yang disampaikan dapat dipahami oleh anak didik secara terarah, terstruktur dan teruji ketepatan dan keakuratannya. Oleh karena itu, seorang guru masa kini dituntut untuk mampu dan mahir, mampu menggunakan berbagai metode serta model pembelajaran dengan baik dan benar. Menyadari hal ini, maka sudah saatnya seorang guru harus bisa meninggalkan pola dan budaya lama yaitu model pembelajaran yang berpusat segala sesuatunya kepada guru, karena hal demikian ini sudah kuno dan ketinggalan zaman. Peran guru pada metode lama ini sangat lengkap, karena guru lebih aktif didepan kelas ketimbang anak didiknya. Guru lebih banyak berbuat dan berbicara melalui metode ceramah di depan kelas, disamping tugas guru lainnya untuk memberikan motivasi, membimbing, mengarahkan dan melakukan penilaian kepada siswa. Hal ini akan berdampak buruk pada siswanya, siswanya akan bersifat pasif, karena hanya mencawan atau menerima apa yang disuguhkan oleh guru kepadanya, siswa tidak bisa berkreasi, belajar mencari dan menemukan sendiri. Akibatnya hasil akhir dari proses pembelajaran yang dilaksanakan, belum mencapai hasil yang optimal dan maksimal. Solusi dari semua persoalan ini adalah seorang guru harus mampu melakukan perubahan. Perubahan tersebut antara lain seperti perubahan model pembelajaran yang tradisional (model atau metode pembelajaran yang lebih berpusat pada guru) kepada pengembangan model atau metode yang lebih berpusat pada siswa dalam pembelajaran. Pendekatan pembelajaran yang sebelumnya lebih banyak didominasi oleh guru harus diperbaharui dan diubah menjadi sistem pembelajaran yang berpusat pada siswa. Langkah terobosan baru ini dinilai sangat bijak dan tepat, mengingat bahwa Peran guru dalam konteks pembelajaran menuntut perubahan, antara lain: (a) peranan guru sebagai penyebar informasi semakin kecil, tetapi lebih banyak berfungsi sebagai pembimbing, penasehat, dan pendorong, (b) siswa adalah individu-individu yang kompleks, yang berarti bahwa mereka mempunyai perbedaan cara belajar, (c) proses belajar mengajar lebih ditekankan pada belajar daripada mengajar.

Dari hasil evaluasi yang peneliti lakukan, diperoleh bahwa kegiatan proses pembelajaran di kelas yang dilaksanakan melalui metode tradisional selama ini, terbukti mempunyai banyak kekurangan dan kelemahan. Kekurangan dan kelemahan tersebut dapat dilihat pada saat proses pembelajaran yang sedang berlangsung di kelas, interaksi aktif antara siswa yang satu dengan siswa yang lainnya, maupun antara siswa dengan guru yang amat jarang terjadi. Terlihat bahwa saat proses pembelajaran sedang berlangsung, siswa berlaku pasif, kurang terampil menjawab pertanyaaan dari guru ataupun memberikan pertanyaan pada guru tentang sesuatu hal yang tidak dipahami atau kurang dimengerti olehnya. Begitu pula saat guru membentuk kelompok diskusi dalam belajar, terlihat dengan jelas bahwa siswa tersebut kurang bisa bekerja dalam kelompok diskusinya tersebut dan siswa juga tidak dapat memecahkan masalah atau mencarikan solusi dari persoalan yang diberikan oleh guru. Mereka lebih cenderung belajar secara individual atau sendiri-sendiri, sehingga pengetahuan yang mereka peroleh dikembangkan sendiri berdasarkan atas pemahamannya sendiri pula.

Dari hasil evaluasi dan pengkajian yang dilakukan, ternyata metode atau pendekatan pembelajaran yang bersifat tradisonal melahirkan hasil belajar yang belum maksimal dan optimal. Hal ini tampak pada pencapaian nilai akhir siswa itu sendiri, dimana hanya sekitar 20 sampai $30 \%$ saja siswa yang nilainya mencapai 
target KKM yaitu 65. Rendahnya pencapaian nilai akhir siswa ini, menjadi indikasi bahwa pembelajaran yang dilakukan selama ini dinilai belum efessien dan efektif. Nilai akhir dari evaluasi belajar belum mencakup penampilandan partisipasi siswa dalam pembelajaran, sehingga sulit untuk mengukur keterampilan siswa dalam menjawab soal atau memecahkan masalah yang diberikan oleh gurunya.

Tidak dipungkiri, bahwa berdasarkan kenyataan selama ini, mata pelajaran PPKn adalah salah satu dari mata pelajaran yang dianggap siswa sebagai mata pelajaran yang membosankan karena sarat dengan materi teoritis. Maka dari itu sepatutnya dan seyogyanya sebagai seorang guru PPKn mencari dan menemukan jalan keluar dari persoalan ini yaitu dengan membuka paradigma baru dalam pola pengajaran di kelas. Hasil yang diharapkan bahwa mata pelajaran PPKn yang selama ini dianggap sebagai mata pelajaran yang membosankan dan membuat mata mengantuk akan mampu berobah menjadi pelajaran yang menyenangkandan mengasyikkan. Untuk mewujudkan semua ini tentulah seorang guru harus mampu berbuat kreatif dan berinovatif, karena guru harus mampu menyiapkan, menyusun suatu pendekatan dalam pembelajaran yang lebih komprehensif dan dapat mengaitkan materi dengan pengalaman-pengalaman belajar yang inovatif, menantang dan menyenangkan sehingga mampu membawa perubahan terhadap hasil akhir siswa sesuai dengan yang diharapkan bersama.

Salah satu dari berbagai model pembelajaran yang dapat mengakomodasi kepentingan untuk mengkolaborasikan pengembangan diri siswa di dalam proses pembelajaran adalah model pembelajaran kooperatif (Cooperative Learning). Pembelajaran kooperatif adalah: suatu proses yang membelajarkan siswa berbagai keterampilan, penciptaan kerjasama atau kolaborasi. Pembelajaran kooperatif merupakan salah satu model pembelajaran dimana siswa belajar dalam kelompok kecil yang heterogen di kelas kemudian dikelompokkan dengan tingkat kemampuan yang berbeda. Slavin dalam Isjoni (2007: 15) menjelaskan bahwa pembelajaran kooperatif merupakan model pembelajaran dimana siswa belajar dan bekerja dalam kelompok-kelompok kecil secara kolaboratif yang anggotanya 5 orang dengan struktur kelompok heterogen. Sugiyanto (2010:37) menjelaskan bahwa pembelajaran kooperatif adalah model pembelajaran yang berfokus pada pembagian siswa ke dalam kelompok kecil siswa untuk saling bekerja sama dalam memaksimalkan kondisi belajar untuk mencapai tujuan pembelajaran. Dalam setiap kelompok belajar, terdapat siswa yang berkemampuan rendah, sedang, dan tinggi. Dengan model pembelajaran yang kooperatif ini diharapkan setiap siswa mampu menyelesaikan tugas-tugas yang diberikan guru kepadanya melalui kolaborasi atau kerjasama antar setiap anggota dalam kelompok belajar dengan saling membantu untuk memahami dan menyelesaikan bahan pembelajaran yang mereka pelajari.

Dalam upaya meningkatkan partisipasi dan keaktifan setiap siswa dalam kegiatan proses belajar mengajar yang berlangsung didalam kelas, maka seorang guru dalam kesempatan ini dapat menerapkan salah satu dari model pembelajaran kooperatif yang ada yaitu melalui model pembelajaran kooperatif tipe Make A Match ". Suyatno (2009:72) menjelaskan bahwa model pembelaran koopertaif tipe Make A Match adalah sistim pembelajaran yang mengutamakan penanaman kemampuan sosial terutama kemampuan bekerjasama, kemampuan beriteraksi disamping itu juga kemampuan berfikir cepat dan mengasyikkan melalui bentuk 
permainan mencari pasangan dengan dibantu oleh kartu soal dan kartu jawaban yang sudah disediakan oleh guru sebelumnya. Sementara itu Isjoni (2007:77) menyatakan bahwa model pembelajaran make a match merupakan model pembelajaran mencari pasangan sambil belajar konsep dalam suasana yang menyenangkan. Model pembelajaran kooperatif tipe Make A Match atau metode teka teki berpasangan ini merupakan salah satu alternatif yang dapat diterapkan oleh guru kepada siswa di kelasnya. Sintak atau langkah guru dalam penerapan metode ini dimulai dari persiapan seorang guru untuk membuat kartu soal pertanyaan dan kartu jawaban, selanjutnya beberapa orang siswa disuruh berdiri di depan kelas untuk memilih secara acak kartu soal maupun kartu jawabannya yang sudah diatur oleh guru sebelumnya. Selanjutnya setiap siswa ditugaskan mencari pasangan antara kartu soal dengan kartu jawaban yang jawabannya sesuai, tepat dan benar sebelum batas waktu yang ditentukan oleh guru habis. Bagi siswa yang dapat mencocokkan antara kartu soal dengan kartu jawabannya disuruh menampilkan atau menempelkannya di papan tulis dan atas keberhasilannnya itu, guru akan memberikan poin berupa nilai, sedangkan bagi siswa yang tidak berhasil akan diberihukuman positif yang bersifat mendidik yang sudah disepakati antara guru dengan siswa sebelum kegiatan pembelajaran itu berlangsung.

Diharapkan dengan pemilihan dan penentuan metode atau model pembelajaran yang jitu dan tepat dalam kegiatan proses pembelajaran PPKn itu, akan lebih mampu menciptakan situasi kondisi belajar antara guru dengan siswanya yang lebih akrab, asyik, hangat, bergairah dan bersemangat, sehingga polemik negatif yang dialami dan dirasakan sendiri oleh siswa selama ini yang menganggap bahwa PPKn adalah mata pelajaran yang jenuh, bikin mengantuk dan membosankan secara perlahan akan mulai hilang dan habis sama sekali. Siswa akan mulai merasakan dan menyadari bahwa belajar PPKn kini tidak lagi membosankan, mengantuk atau menjemukan. Sehingga untuk selanjutnya nanti, melalui pembelajaran kooperatif dengan menerapkan model pembelajaran kooperatif tipe Make A Match ini siswa diharapkan dapat meningkatkan motivasi, kreatifitas, serta kemampuan berpikir mandiri mereka yang bermuara akhir pada peningkatan hasil belajar mereka sendiri terutama dalam mata pelajaran PPKn ini.

Berdasarkan uraian pada latar belakang masalah penelitian di atas, maka peneliti melaksanakan penelitian tindakan kelas dengan judul "Upaya Meningkatkan Hasil Belajar Siswa Menggunakan model pembelajaran kooperatif tipe Make A Match di Kelas VIII UPTD SMP Negeri3Kec.Akabiluru Tahun Pelajaran 2020/2021". Rumusan masalah yang ingin dipecahkan dalam penelitian ini adalah: " Upaya Meningkatkan Hasil Belajar Siswa dengan menerapkan model pembelajaran kooperatif tipe Make A Match di Kelas VIII UPTD SMP Negeri 3 Kec. Akabiluru Tahun Pelajaran 2020/2021". Tujuan dari penelitian tindakan kelas ini adalah untuk mengetahui peningkatan hasil belajar siswa di kelas VIII UPTD SMP Negeri $3 \mathrm{Kec}$. Akabiluru dalam pembelajaran mata pelajaran PPKn dengan menerapkan model pembelajaran kooperatif tipe Make A Match.

\section{METODOLOGI}

Jenis penelitian ini adalah Penelitian Tindakan Kelas (PTK) yang bertujuan untuk meningkatkan hasil belajar siswa dalam pembelajaran mata pelajaran 
Pendidikan Pancasila Kewarganegaraan, dengan tujuan agar para siswa dapat terlibat partispasi dalam kegiatan proses pembelajaran yang akan berimbas terhadap peningkatan hasil belajar siswa itu sendiri. Suharsimi Arikunto (2008: 3) berkesimpulan penelitian tindakan adalah "Suatu pencermatan terhadap kegiatan belajar berupa sebuah tindakan yang sengaja dimunculkan dan terjadi dalam sebuah kelas secara bersama. Tindakan tersebut diberikan oleh guru atau dengan arahan dari guru yang dilakukan oleh siswa". Penelitian ini dilaksanakan di UPTD SMP Negeri 3 Kecamatan Akabiluru Tahun Pelajaran 2020/2021. Sekolah Menengah Pertama Negeri 3 Akabiluru ini berlokasi di Jorong Piladang Kenagarian Koto Tangah Batu Ampa, Kecamatan Akabiluru, Kabupaten Lima Puluh Kota. Dalam penelitian ini yang menjadi Subjek penelitian adalah siswa kelas VIII di UPTD SMP Negeri 3 Kec. Akabiluru, Tahun Pelajaran 2020/2021 dalam pembelajaran PPKn. Di kelas VIII ini siswanya berjumlah 26 orang, terdiri dari 15 orang siswa laki-laki dan 11 orang siswa perempuan.

Instrumen yang digunakan dalam penelitian ini yaitu lembar obervasi aktivitas guru, lembar observasi aktivitas siswa, dan tes hasil belajar siswa. Data yang dikumpulkan dalam penelitian ini dianalisa secara kualitatif dan kuantitatif.

1. Lembar Observasi Siswa

Untuk menganalisa data yang terkumpul mengenai aktivitas siswa, maka peneliti menggunakan teknik persentase menurut Suharsimi Arikunto (2010) dengan rumus sebagai berikut :

$$
P=\frac{f}{N} x 100 \%
$$

Keterangan :

$$
\begin{aligned}
& \mathrm{P}=\text { Persentase aktivitas siswa } \\
& \mathrm{f}=\text { Jumlah siswayang terlibat dalam setiap aktivitas } \\
& \mathrm{N}=\text { Jumlah siswayang hadir }
\end{aligned}
$$

Kemudian Nilai yang diperoleh dikonfirmasikan dengan Kriteria peringkat di bawah ini:

\begin{tabular}{|c|c|}
\hline PERINGKAT & NILAI \\
\hline Amat Baik ( A) & $90 \leq \mathrm{A} \leq 100$ \\
\hline Baik (B) & $75 \leq \mathrm{B}<90$ \\
\hline Cukup (C) & $60 \leq \mathrm{C}<74$ \\
\hline Kurang (K) & $<60$ \\
\hline
\end{tabular}

2. Hasil Belajar siswa

Data hasil belajar siswa yang diperoleh dari tes yang diberikan setiap siklus untuk melihat ketuntasan belajar siswa. Hasilnya siswa yang dapat dikategorikan sebagai siswa yang tuntas adalah apabila nilai yang diperolehnya lebih besar atau sama dengan 65, karena kriteria ketuntasan minimum (KKM) untuk pelajaran PPKn di kelas VIII ini adalah 65. Tindakan dalam penelitian ini dianggap berhasil apabila $80 \%$ siswa tersebut memperoleh nilai di atas KKM.

\section{HASIL PENELITIAN DAN PEMBAHASAN}

\section{Prasiklus}

Pra-siklus dilaksanakan agar peneliti mempunyai data awal terhadap siswa yang akan diteliti. Dalam penelitian ini, peneliti mengambil kelas VIII 
sebagai subyek penelitian. Hasil belajar siswa pada kegiatan Pra-Siklus ini dilakukan dengan melaksanakan Penilaian Harian $(\mathrm{PH})$ yang mana hasilnya adalah 10 orang siswa yang tuntas $(38,46 \%$,) serta 16 orang siswa $(61,53 \%)$ dinyatakan tidak tuntas, karena memperoleh nilai di bawah KKM yang telah ditetapkan di awal tahun pelajaran (65). Nilai tertinggi yang diperoleh siswa adalah 70 dan nilai terendah adalah 25 . Hal inilah faktor pendorong yang sangat kuat bagi peneliti untuk melakukan kegiatan penelitian tindakan kelas ini. Pada kegiatan Pra-Siklus ini, peneliti selaku guru masih melaksanakan proses pembelajaran secara konvensional artinya peneliti belum menerapkan model pembelajaran kooperatif tipe Make A Match ini ke dalam proses pembelajaran. Dalam kegiatan Pra-Siklus ini juga, observer belum lagi melakukan pengamatan secara langsung terhadap aktivitas belajar siswa maupun pengamatan terhadap aktivitas guru. Jadi semua kegiatan proses pembelajaran yang terjadi di kelas, berlangsung secara konvensional seperti pada kegiatan proses pembelajaran sebelumnya. Harapan peneliti melalui kegiatan penelitian Tindakan Kelas ini adalah dapat membawa pengaruh serta manfaat positif terhadap peningkatan nilai siswa khususnya pada mata pelajaran PPKn khususnya disekolah ini. Hasil belajar siswa pada kegiatan PraSiklus ini adalah 10 orang siswa yang tuntas $(38,46 \%$,) dan ada 16 orang siswa yang tidak tuntas $(61,53 \%)$. Rata-rata hasil belajar siswa pada kegiatan PraSiklus ini adalah 56,73 dengan Perolehan nilai tertinggi adalah: 70, terendahnya adalah: 25 .

\section{Siklus 1}

a. Perencanaan

Penelitian dilakukan dengan Kompetensi Dasar: "Menganalisis makna dan arti Kebangkitan Nasional dalam perjuangan Kemerdekaaan Indonesia." Perencanaan untuk siklus I meliputi:

1) Menentukan Kompetensi Dasar: "Menganalisis makna dan arti Kebangkitan Nasional dalam perjuangan Kemerdekaaan Indonesia."

2) Merancang skenario pembelajaran (RPP) yaitu RPP 3.4.

3) Menyiapkan bahan ajar sesuai dengan indikator:

a) Mendeskripsikan tentang asal usul dan arti istilah Budi Utomo.

b) Menganalisis tentang organisasi pergerakan nasional Budi Utomo Tahun 1908.

c) Menampilkan pasangan kartu soal dengan kartu jawaban yang sesuai tentang materi Organisasi Pergerakan Nasional Budi Utomo tahun 1908.

d) Menyiapkan Instrumen penelitian.

b. Pelaksanaan

Pelaksanaan penelitian pada Siklus I pertemuan 1 dilaksanakan pada hari Senin, tanggal 01 Februari 2021, sedangkan Siklus I pertemuan 2 dilaksanakan pada hari Senin, tanggal 08 Februari 2021. Bertolak dari tujuan penelitian yang telah dikemukakan sebelumnya, yaitu untuk meningkatkan hasil belajar siswa dengan menggunakan model pembelajaran kooperatif tipe Make A Match di kelas VIII UPTD SMP Negeri 3 Kec. Akabiluru, maka pelaksanaan penelitian mengacu pada indikator di atas yaitu hasil belajar siswa itu sendiri. Pada pelaksanaan tindakan ini, peneliti melakukan 
pembelajaran dengan menggunakan model pembelajaran kooperatif tipe Make A Match sesuai dengan RPP yang telah dirancang sebelumnya

c. Pengamatan

Pengamatan dilakukan dengan bantuan guru kolaborator yang telah disepakati sebelum penelitian. Pada penelitian ini peneliti berkolaborasi dengan Bapak Rizal, S.Pd. Pengamatan dilaksanakan dengan memberikan ceklis pada lembar observasi yang telah dipersiapkan sebelumnya, baik lembar observasi aktivitas guru maupun lembar observasi aktivitas siswa. Berdasarkan temuan dari observasi yang dilaksanakan oleh teman kolaborasi peneliti dapat uraikan sebagai berikut:

1) Observasi aktivitas Siswa

Pada kegiatan pendahuluan, siswa telah melaksanakan aktivitas meresepon salam guru dan berdoa sebelum belajar dengan sempurna. Dari dua kali pertemuan di siklus I ini, siswa memperolah nilai rata-rata 100. Namun pada kegiatan lainya masih dalam kategori kurang. Pada kegiatan inti, dapat dijelaskan bahwa belum semua siswa yang memperhatikan guru memberikan penjelasan konsep secara umum, siswa belum membaca dan menelaah materi pembelajaran yang ada di dalam buku paket dengan baik, siswa belum memperhatikan guru menyiapkan beberapa kartu yang berisi beberapa konsep atau topik yang cocok untuk sesi review, belum semua siswa yang dapat mencocokkan kartunya sebelum batas waktu yang ditentukan akan diberikan nilai/poin, dan belum semua siswa memperhatikan guru mengkonfirmasi jawaban siswa dengan baik. Data menunjukkan ratarata temuan untuk semua langkah tersebut adalah 50\%. Namun ada beberapa langkah yang telah diikuti siswa dengan sempurna yaitu siswa menerima satu buah kartu secara acak, siswa yang mendapatkan kartu telah memikirkan isi kartu yang dipegangnya, kemudian mencari pasangan dan menempelkan kartu di papan tulis, dan setelah satu babak, kartu dikocok lagi agar tiap siswa mendapat jatah kartu. Selanjutnya, pada kegiatan penutup siswa belum memperhatikan dan merespon guru menyimpulkan pelajaran dengan baik. Namun siswa dapat merespon salam guru sebagai penutup pertemuan dengan baik. Terakhir dapat disimpulkan bahwa hasil yang diperoleh berdasarkan lembar observasi aktivitas siswa masih dalam kategori rendah. Rata-rata nilai perolehan dari lembar observasi aktivitas siswa adalah 68,75. Perolehan Nilai tersebut termasuk pada peringkat Cukup.

2) Observasi aktivitas Guru

Dari hasil observasi terlihat bahwa secara umum guru telah melaksanakan pembelajaran dengan baik. Hal ini terlihat dari nilai ratarata perolehan guru berdasarkan lembar observasi aktivitas guru pada siklus I yang terdiri dari 2 pertemuan yaitu dengan nilai 78,13. Nilai 78,13ini termasuk peringkat nilai Baik. Namun, pada beberapa langkah pembelajaran masih ditemui nilai kurang. Pada kegiatan Pendahuluan guru belum mencek kehadiran siswa pada pertemuan 1 dan pada pertemuan 2 sudah terlaksana dengan baik. Namun guru belum mengkondisikan siswa agar siap menerima pelajaran dan memberikan apersepsi awal pelajaran dan guru belum menyampaikan indikator 
pencapaian kompetensi. Pada Kegiatan inti, ada tiga langkah yang masih kurang yaitu guru belum memberikan penjelasan konsep secara umum dan guru belum memberikan nilai pada siswa yang dapat mencocokkan kartunya sebelum batas waktu yang ditentukan habis. Pada kegiatan Penutup, guru belum menyimpulkan pembelajaran. Dari pengamatan, dapat dilihat bahwa guru belum menyimpulkan pembelajaran, hal ini disebabkan karena guru tidak memiliki waktu yang cukup dalam pembelajaran.

3) Penilaian Harian ( PH ) Siklus I

Pada pertemuan ketiga pada siklus I, peneliti melaksanakan penilaian Harian (PH). Penilaian Harian ini dilaksanakan dalam bentuk soal uraian yang terdiri dari lima butir soal. Siswa diminta menjawab soal pada lembar jawaban yang telah disediakan. Waktu yang dialokasikan adalah 60 menit.Penilaian diikuti oleh 24 orang siswa, sementara 2 orang siswa tidak hadir pada hari tersebut. Penilaian Harian (PH) Siklus I ini dilaksanakan pada Hari Senin, tanggal 22 Februari 2021. Hasil PH menunjukkan ada 14 orang $(53,84 \%)$ siswa sudah tuntas berarti nilai mereka sama atau melebihi KKM yang telah ditetapkan, dan siswa yang belum tuntas adalah 10 orang $(38,46 \%)$. sedangkan ratarata nilai yang diperoleh adalah 61,34 dengan nilai perolehan tertinggi adalah: 100, sedangkan nilai terendahnya adalah: 25 .

d. Refleksi

Dari hasil analisis data observasi, dapat disimpulkan bahwa pelaksanaan model Make A Match cukup mempengaruhi hasil belajar siswa. hal ini dapat dilihat dari rata-rata peningkatan persentase hasil belajar siswa pada siklus 1. Dilihat secara total persentase hasil belajar siswa berdasarkan perolehan hasil dari pelaksanaan PH Siklus 1 yang baru mencapai 14 orang (54\%), hal ini berarti belum memenuhi indikator keberhasilan yang telah ditetapkan sesuai KKM yaitu 65, sehingga peneliti berketetapan untuk perlu dilanjutkan ke siklus 2. Dari hasil observasi dan refleksi pada kegiatan siklus I, maka ditemukanlah beberapa kelemahan seperti berikut:

1) Masih terdapat siswa yang belum memahami tentang alur proses/urutan langkah-langkah pada model pembelajaran kooperatif tipe Make A Match ini, sehingga guru perlu mengadakan kegiatan sosialisasi kembali dengan membuat langkah-langkah kerja tersebut sesuai model pembelajaran di atas.

2) Masih banyak siswa yang malu bertanya pada guru, terbukti dengan persentase aktivitas mengajukan pertanyaan kepada guru pada siklus I pertemuan satu, dua dan tiga masih kurang.

3) Sekitar 4 sampai 5 orang siswa masih susah untuk fokus belajar dan bekerja serius (terlibat santai,asyik ngobrol dengan teman)

4) Suasana kelas terasa agak kaku, karena kehadiran observer didalam lokalnya, meski sudah disosialisasikan sebelumnya.

Berdasarkan kelemahan-kelemahan yang ditemukan pada siklus I, maka peneliti perlu mencarikan solusinya dengan melakukan revisi terhadap tindakan yang telah dilakukan, antara lain: menjelaskan kembali langkah-langkah kerja model pembelajaran kooperatif tipe Make A Match ini, memfasilitasi siswa yang belum mengerti, membimbing siswa yang 
lamban secara individu, mensosialisasikan kepada peserta kehadiran observer, mengefisienkan waktu, dan memberikan arahan dan pengertian pada siswa yang mengobrol. Untuk merealisasikan tindakan-tidakan tersebut, maka peneliti perlu untuk melanjutkan kepada siklus yang kedua.

\section{Siklus 2}

\section{a.Perencanaan}

Penelitian dilakukan dengan menyiapkan Kompetensi Dasar: "Memproyeksikan nilai dan semangat Sumpah Pemuda tahun 1928 dalam bingkai Bhinneka Tunggal Ika " Perencanaan untuk siklus II ini meliputi :

1) Menentukan Kompetensi Dasar: "Memproyeksikan nilai dan semangat Sumpah Pemuda tahun 1928 dalam bingkai Bhinneka Tunggal Ika"

2) Merancang skenario pembelajaran (RPP) yaitu RPP.3.5

3) Menyiapkan bahan ajar sesuai dengan indikator:

a) Mendeskripsikan tentang pengertian pemuda menurut kamus besar Bahasa Indonesia

b) Mendeskripsikan tentang pengertian pemuda menurut UU Nomor 40 tahun 2009-tentang kepemudaan

c) Menguraikan tentang nama-nama panitia pada kongres pemuda kedua tanggal 28 Oktober 1928

d) Mendeskripsikan tentang makna Sumpah Pemuda dalam upaya mewujudkan kemerdekaan Indonesia

e) Menampilkan pasangan kartu soal dengan kartu jawaban yang sesuai tentang peran perjuangan pemuda dalam perjuangan kemerdekaan Indonesia.

4) Menyiapkan Instrumen penelitian.

b. Pelaksanaan

Pelaksanaan penelitian pada siklus II pertemuan 1 adalah pada hari Senin tanggal 01 Maret 2021. Pertemuan 1 ini dlaksanakan selama 3 jam pelajaran. Sedangkan Siklus II Pertemuan 2 dilaksanakan pada hari Senin 08 Maret 2021. Kedua pertemuan pada siklus II ini diamati oleh guru Kolaborator teman peneliti sebagai observer. Pada pelaksanaan tindakan ini, peneliti melakukan pembelajaran dengan menggunakan model pembelajaran kooperatif tipe Make A Match sesuai dengan RPP yang telah dirancang.

c. Pengamatan

1) Observasi aktivitas Siswa

Aktivitas siswa dalam merespon salam guru adalah 100\%. Secara umum aktivitas siswa sudah sangat baik hampir semua kegiatan diikuti oleh siswa dengan seksama, sehingga kelas menjadi lebih hidup dan menyenangkan. Hanya pada kegiatan "Memperhatikan guru menginformasikan tujuan pembelajaran yang harus dicapai dan langkah-langkah pembelajaran yang dilaksanakan" yang masih 50\% memperhatikan guru.Pada pertemuan pertama siswa sebagian besar belum memperhatikan guru dalam menginformasikan tujuan pembelajaran dan pada pertemuan kedua guru lebih memberikan perhatian dan mengingatkan siswa agar memperhatikan guru dalam penyampaian tujuan pembelajaran dan hasilnya hampir semua siswa memperhatikan guru pada kegiatan tersebut.Kegiatan "Setiap siswa yang dapat mencocokkan kartunya sebelum batas waktu yang 
ditentukan akan diberikan nilai/poin" guru belum maksimal memberikan poin nilai kepada siswanya.

Berdasarkan uraian data di atas, kegiatan proses pembelajaran yang berlangsung pada siklus kedua ini telah terjadi perubahan atau peningkatan lebih berarti jika dibandingkan dengan kegiatan proses pembelajaran pada siklus pertama. Fakta ini secara umum dapat memberikan kesimpulan bahwa melalui model pembelajaran kooperatif tipe Make A Match yang dilaksanakan dalam penelitian ini ternyata mampu meningkatkan motivasi belajar siswa. Karena terdapat peningkatan baik dari segi kwantitas maupun kwalitas siswa dari setiap pertemuan mulai dari siklus I sampai siklus II ini.

2) Observasi aktivitas Guru

Dari hasil observasi terlihat bahwa secara umum guru sudah melaksanakan proses pembelajaran PPKn di kelas VIII dengan menggunakan model pembelajaran kooperatif tipe Make A Match dengan sempurna. Semua langkah-langkah pembelajaran sudah terlaksana dengan baik. Rata-rata hasil observasi aktivitas guru adalah sebesar 100 pada siklus II

3) Penilaian Harian ( PH ) Siklus II

Penilaian Harian Siklus II ini bertujuan untuk melihat sampai dimana capaian siswa tentang materi yang diberikan dengan menggunakan model pembelajaran kooperatif tipe Make A Match. Penilaian Harian dilaksanakan pada tanggal 22 Maret 2021. Ada 26 orang siswa yang mengikuti tes. Tes dilaksanakan dengan menggunakan soal bentuk uraian sebanyak 5 buah soal. Waktu yang disediakan untuk siswa menjawab soal adalah selama 60 menit. Dari hasil penilaian masih ada 3 orang $(11,54 \%)$ siswa yang belum tuntas pada pelaksanaan PH di siklus II ini. Sedangkan 23 orang $(88,46 \%)$ siswa sudah tuntas dengan KKM adalah 65. Perolehan nilai mereka berkisar antara 65-100. Nilai rata-rata yang diperoleh siswa adalah 81,88 . Nilai tertinggi siswa adalah 100 , sedangkan nilai terendahnya adalah: 60 .

\section{d. Refleksi}

Berdasarkan hasil penelitian diketahui bahwa indikator keberhasilan telah tercapai. Peneliti dapat menyimpulkan bahwa melalui model pembelajaran kooperatif tipe Make A Match dapat meningkatkan hasil belajar siswa di kelas VIII UPTD SMP Negeri 3 Kecamatan Akabiluru Tahun Pelajaran 2020/2021, hal ini dapat dibuktikan Sehingga dengan demikian penelitian ini dicukupkan untuk dilakukan sampai pada siklus II ini.

\section{Pembahasan}

Berdasarkan temuan pada sikluis I dan II, maka peneliti dapat menjelaskan beberapa hal terkait dengan pelaksanaan penelitian tindakan kelas yang peneliti laksanakan di kelas VIII ini. Penelitian dilaksanakan pada Semester 2 Tahun Pelajaran 2020/2021 di UPTD SMPN 3 Kecamatan Akabiluru. Hasil yang diperoleh adalah sebagai berikut: 


\section{Peningkatan aktivitas siswa dari siklus I ke siklus II.}

Secara umum terjadi peningkatan aktivitas belajar siswa melalui pembelajaran dengan menggunakan model pembelajaran kooperatif tipe Make A Match pada mata pembelajaran PPKn di kelas VIII. Dari rata-rata perolehan pada siklus I ini adalah 68,75 berubah menjadi 93,75. Rata-rata perolehan adalah 81,25 dengan peningkatan dari siklus I ke siklus II adalah sebesar 25 persen. Selanjutnya data dapat disajikan dalam bentuk grafik di bawah ini:

\section{Grafik Peningkatan Aktifitas Siswa dari Siklus I ke Siklus II}

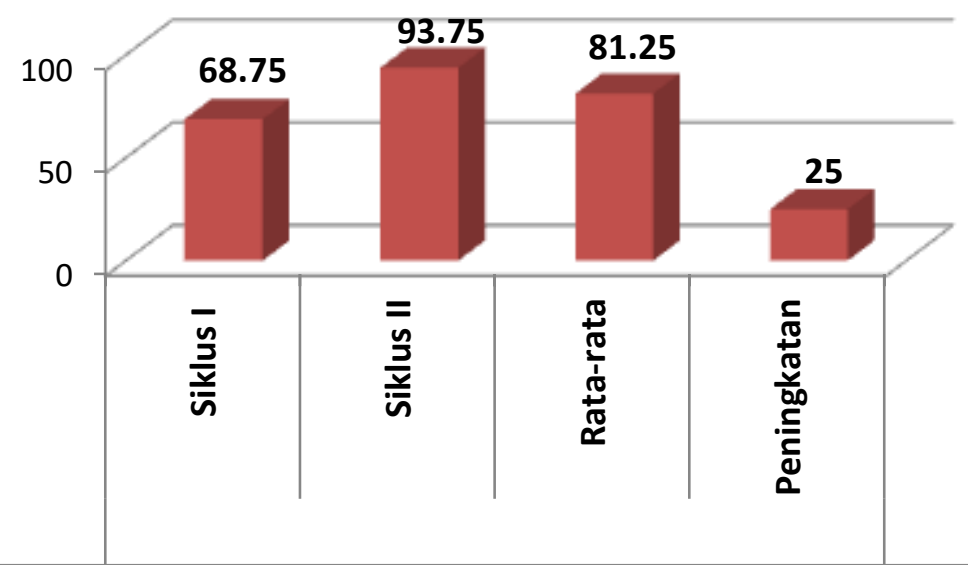

Grafik 1. Peningkatan Aktifitas Siswa dari Siklus I ke Siklus II

Dari Grafik di atas dapat dijelaskan bahwa pada siklus I rata-rata perolehan nilai dari lembar observasi aktivitas siswa adalah 68,75. Nilai ini menggambarkan bahwa aktivitas siswa belum terarah dengan baik. Berdasarkan pengamatan peneliti bahwa aktivitas siswa masih belum terbiasa dengan langkah-langkah pembelajaran. Pada siklus II diperoleh hasil rata-rata 93,75. Dari temuan pada siklus II ini terjadi peningkatan yang sangat besar dibandingkan dengan temuan pada Siklus I. Hal ini disebabkan karena pada siklus II ini, siswa telah terbiasa dengan langkah-langkah pembelajaran kooperatif ini, sehingga mereka sangat semangat dan terarah dalam melaksanakan tugas-tugas yang diberikan guru. Hampir semua siswa dapat berpartisipasi langsung dalam kegiatan pembelajaran ini. Rata-rata perolehan nilai dari lembar observasi aktivitas siswa siklus I dan Siklus II adalah 81,25. Nilai ini menandakan bahwa aktivitas siswa adalah Baik (B). Selanjutnya, peningkatan nilai yang diperoleh dari siklus I ke siklus II adalah $25 \%$.

2. Peningkatan aktivitas guru dari siklus I ke siklus II.

Rata-rata perolehan nilai observasi guru yang diamati oleh guru kolaborator pada siklus I adalah 78,13 dengan perolehan tersebut dapat diperoleh data bahwa belum semua langkah pembelajaran terlaksana dengan baik oleh guru. Masih ada beberapa langkah yang terabaikan dan belum terlaksana dengan baik. Setelah dilksanakan refleksi di akhir siklus I, maka peneliti dan guru kolaborator memproleh informasi tentang kelemahan dan keunggulan pelaksanaan pembelajaran dengan menggunakan model pembelajaran kooperatif tipe Make A Match. Oleh sebab itu peneliti memperbaiki dan mengikuti langkah-langkah pembelajaran sesuai dengan 
yang tertulis pada RPP pada pelaksanaan siklus II. Maka perolehan rata-rata nilai observasi aktivitas guru adalah 100.dengan demikian semua langkah pada pembelajaran sudah terlaksana dengan baik. Peningkatan perolehan nilai observasi aktivitas guru dari siklus I ke siklus II adalah $21,87 \%$ dengan perolehan nilai rata-rata adalah 89,07. Dari hasil temuan ini dapat disimpulkan bahwa dengan menggunakan model pembelajaran kooperatif tipe Make A Match dapat meningkatkan aktivitas guru dalam pembelajaran PPKn di UPTD SMPN 3 Kecamatan Akabiluru. Selanjutnya, data dapat disajikan dengan grafik dibawah ini:

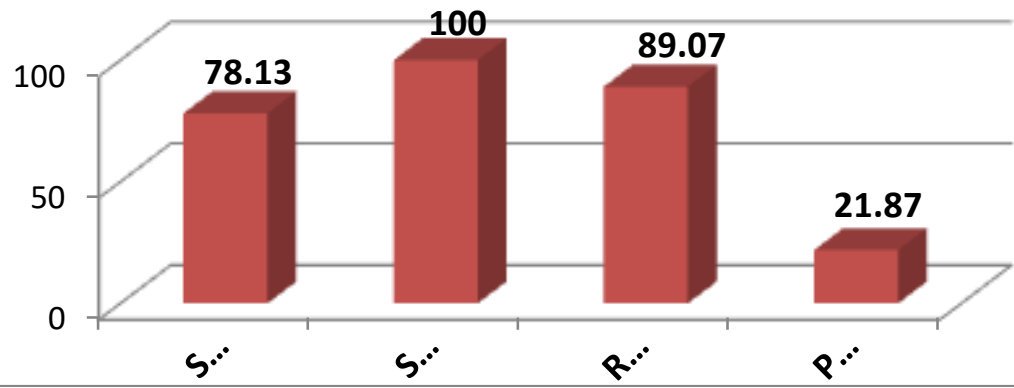

Grafik 2. Peningkatan Aktifitas Guru dari Siklus I ke Siklus II

Dari grafik dapat dilihat rata perolehan nilai aktivitas guru pada siklus I adalah 75. Setelah dilaksanakan siklus II maka perolehan nilai meningkat rata-ratanya menjadi 100. Dari perolehan siklus I dan siklus II dapat dirata-ratakan menjadi 87,5. Dari data tersebut dapat dipahami bahwa pada siklus I guru belum melaksanakan pembelajaran dengan menggunakan model pembelajaran kooperatif tipe Make A Match dengan baik. Pada siklus II, guru sudah mampu mengikuti semua langkah-langkah pembelajaran dengan sempurna. Peningkatan aktivitas guru dalam pembelajaran PPKn dengan menggunakan model pembelajaran kooperatif tipe Make A Match dari siklus I ke siklus II adalah $25 \%$.

\section{Peningkatan hasil belajar dari siklus I ke siklus II.}

Pada siklus I diperoleh rata-rata nilai adalah 61.34. Nilai ini masih dalam kategori rendah. Ada 24 siswa yang mengikuti tes siklus I ini, karena ada 2 orang siswa yang tidak hadir pada hari tersebut. Penyebab rendahnya rata-rata nilai pada tes yang dilaksanakan di akhir Siklus I adalah karena siswa belum memahami secara seksama langkah-langkah pembelajaran dan belum belajar dengan maksimal sesuai dengan materi yang diajarkan pada siklus I. Maka pada siklus II, peneliti lebih memperhatikan pemahaman siswa terhadap materi yang mereka pelajari pada pertemuan 1 dan 2 . Selain itu peneliti juga lebih menekankan pembelajaran terhadap materi-materi yang akan diujikan pada siklus II tersebut. Penliti juga memberikan motivasi kepada siswa agar proaktif dan berpartisipasi aktif dalam kegiatan pembelajaran. Selanjutnya, data dari hasil tes siswa kelas VIII pada mata pelajaran PPKn dapat pula disajikan dengan grafik di bawah ini: 


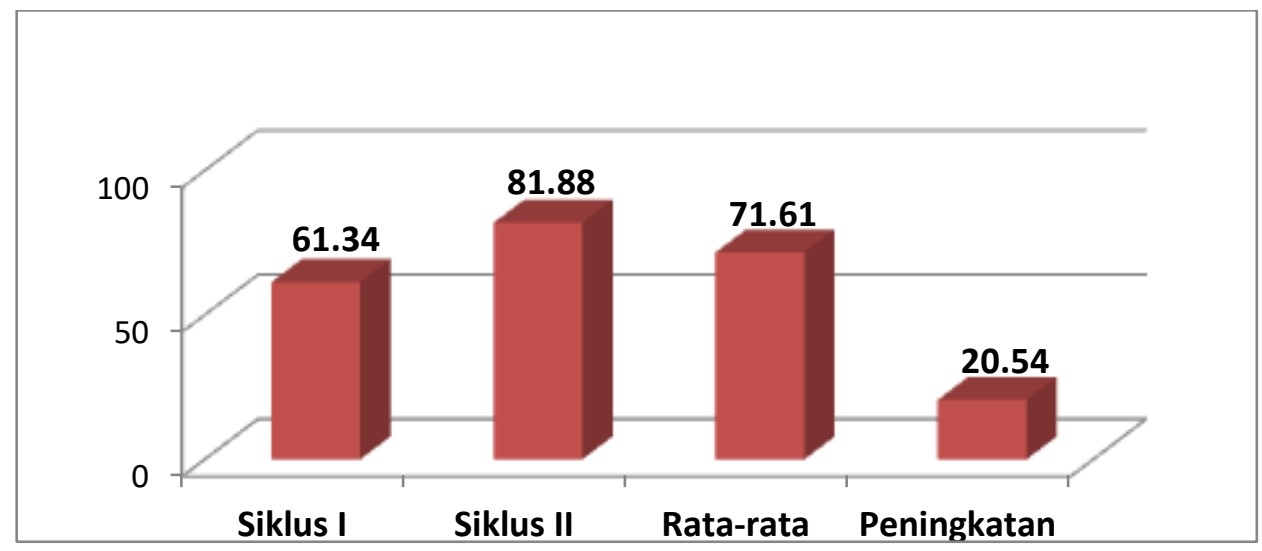

Grafik 3. Peningkatan Hasil Belajar Siswa dari Siklus I ke Siklus II

Sesuai dengan data pada grafik peningkatan hasil belajar siswa di atas dapat dijelaskan bahwa rata-rata perolehan nilai siswa dari hasil tes siklus I dan siklus II adalah sebesar 71,61. Dengan nilai rata-rata ini dapat disimpulkan bahwa sudah semua siswa yang memperoleh nilai tes pada siklus II sama dan melebihi KKM yang telah ditetapkan pada awal pembelajaran. Terjadi peningkatan nilai dari siklus I ke siklus II sebesar 20,54\%.

\section{KESIMPULAN DAN SARAN}

Setelah memperhatikan dan memcermati hasil penelitian di atas, dapat diambil kesimpulan bahwa model pembelajaran kooperatif tipe Make A Match dapat meningkatkan hasil belajar PPKn siswa kelas VIII di SMPN 3 Kecamatan Akabiluru tahun pelajaran 2020/2021.

Setelah mengadakan penelitian dengan model pembelajaran kooperatif tipe Make A Match ini, maka peneliti mengemukakan beberapa saran sebagai berikut:

1. Dalam upaya meningkatkan hasil belajar siswa dalam kegiatan pembelajaran yang berlangsung disekolah, sudah selayaknya seorang guru harus berupaya menemukan, menentukan pilihan dan melaksanakan model-model pembelajaran yang tepat sesuai dengan topik KD dan Materi yang diajarkan kepada siswa.

2. Penelitian Tindakan Kelas adalah suatu upaya untuk mengembangkan modelmodel pembelajaran dan strategi pembelajaran untuk mencari solusi bagi guru terhadap berbagai permasalahan yang terjadi di lapangan.

\section{DAFTAR PUSTAKA}

Isjoni. 2007. Cooperatif Learning: Efektivitas Pembelajaran Kelompok. Bandung: Alfabeta.

Sugiyanto. 2010. Model-model Pembelajaran Inovatif. Surakarta: Yuma Pressindo

Suharsimi Arikunto, dkk. 2008. Penelitian Tindakan Kelas. Jakarta: Bumi Aksara.

Suharsimi Arikunto. 2010. Prosedur Penelitian Suatu pendekatan Praktek. Jakarta: Rineka Cipta.

Suyatno, 2009. Menjelajah Pembelajaran Inovatif. Sidoharjo: Masmedia Buana Pustaka. 